\title{
Turkish SMES Corporate Sustainability Approaches: Cluster Analysis Method, an Empirical
} Study

\author{
Özlem TUNA, Ph.D., Lecturer \\ Afyon Kocatepe University \\ Afyon Health School, Health Facilities Management \\ ozltuna@hotmail.com
}

Prof. Dr. Senem BESLER

Anadolu University, Faculty of Economics and Administrative Science,

sbesler@anadolu.edu.tr

DOI:10.5901/mjss.2014.v5n19p175

Abstract

Since sustainable concept was used in 1713 by Carl von Carlowitz as an environmental approach there have been many developments and the concept included economic and social subject and stated being an approach that helps the companies to create long term values. Corporate sustainability which many academicians and researchers worked on especially from 1990's till now have been shaped the national and international business sectors views and been a research subject for many researchers. A few national researches about corporate sustainability are aims on big scale companies. The SMEs which are $99 \%$ of all companies play a key role for employment, added value and manufacturing industry and also they create a big environmental and social impact. For this reason SMEs which a noticeable percentage on all companies and which are quite effective for sustainable development have been choose for this research. In this context, a research on determination of differences in perspectives and approaches of Turkish SMEs to corporate sustainability is included. As second 350 SMEs in Istanbul are investigated with quantative methods and with K-Means non hierarchical clustering technique managers are classified as sustainability leaders, reactives and unconcerns. Thus with this the point of view of companies towards corporate sustainability is detected. It is possible to link the distinction in perspectives of companies within these three groups to different evaluation of the tools of management used in sustainability practices and the forces that lead enterprises to sustainability practices *.

Keywords: Corporate sustainability, corporate social responsibility, sustainability development.

\section{Introduction}

Companies currently operate in a global stakeholder society where they are expected to be accountable to all relevant stakeholders due to wider economic, environmental and social effects instead of being accountable only to shareholders for financial performance. In a rapid and unprecedented environment of competition, sustainability of companies correlates directly with the fulfilment of expectations of all stakeholders. It is very difficult for an enterprise that does not create added value for its stakeholders to continue its existence and carry it into the future. Sustainability objectives suggest private sector companies not only to create value and provide products and services that improve standards of life, but also to become involved in efforts that will actively resolve different environmental and social issues arising from their activities.

Demands of the society in terms of sustainability also reflect on their economic interactions with companies. These demands of the society, which fundamentally defines the criteria for success and ultimately owns all resources required by companies, created a new and significant competitive pressure on companies in both short and long term. Currently, companies are required to compete with each other not only in economic terms, but also in terms of social acceptance. While the society acts more eager to reward companies that it deems to be valuable by allocating resources under its

* This article is derived from the PhD. thesis of Özlem TUNA entitled "Corporate Sustainability Approach and Practices: The Study on SMEs". 
control to these companies; it punishes companies that it deems to be incompetent in satisfying its expectations and obstructs or even attempts to prevent their access to these resources. Therefore, being successful in satisfying expectations of the society has become an important component of the process of competition between companies. Under all these economic, social and environmental factors, companies are required to adopt and internalize corporate sustainability principles that enable them to gain and improve competitive power, as well as shape their business models on the basis of these principles.

Corporate sustainability issue covers all activities and procedures of companies, instead of only their financial activities, and continues its development by broadening its scope. With this object in mind, we wanted to address sustainability, which the companies currently require but fail to maintain due to radical changes in environmental conditions or with their existing structures or practices, with an empirical approach in this research. This research initially reviews the studies in literature on corporate sustainability. In the following chapter, there is a study attempting to manifest the corporate sustainability situation of Turkish SMEs in recent years. A reason for addressing SMEs in our study is that SMEs, comprising $95 \%$ of all companies and $60 \%$ of employees according to OECD data, is considered to be a significant resource for employment and welfare due to their contribution to social stability and general tax income (WBCSD, 2004).

Another reason is that SMEs are positioned as the supplier of many large companies. SMEs in the supply chain have a considerable influence on economic, environmental and social effects of large companies. In this context, sustainability and success of large companies correlate directly with their contributions to sustainability of SMEs. To this effect, it was attempted to identify differences in corporate sustainability perspectives and practices of 350 SMEs operating in Istanbul using cluster analysis method.

\section{Literature Review}

Many studies have been conducted since emergence of the concept of corporate sustainability, as researchers approached the subject from different aspects. Many conceptually (Dyllick ve Hockerts, 2002; Marrewijk ve Werre 2002; Wilson, 2003; Gao ve Zhang, 2006; Montiel, 2008; Signitzer ve Prexl, 2008; Schneider ve Meins, 2011; Callado ve Fensterseifer, 2011) ve uygulamaya (Atkinson, 2000; Nemli, 2004; Salzmann, lonescu-Somers ve Steger, 2005; Hahn ve Scheermesser, 2006; Robinson vd., 2006; Benn, Dunphy ve Griffiths, 2006; Young ve Tilley, 2006; Linnenluecke, Russell ve Griffiths, 2009) oriented studies, that have considerably contributed to improvement of the concept, have been conducted in this respect. Such studies can be outlined in four groups (Besler, 2009):

The first approach involve the studies that address sustainability from economic perspective. In these studies, economic sustainability is addressed as long term economic performance and characterized as the golden boy of paradoxical sustainability. In this approach, it is not approved to launch investments that do not directly affect interests of stakeholders. (Friedman, 1970; Levitt, 1958). The second approach involve the studies that environmentally address sustainability (Shrivastava, 1995; Starik ve Rands, 1995). It is seen that the assumption that companies are not separate from their natural environments, that they are contained within such environments and that they operate therein underlies this concept (Sharma. 2003). The third approach to corporate sustainability involves studies that demand companies to assume greater responsibilities for social environment (Carroll, 1999; Dunphy ve diğerleri, 2003; Freeman, 1984). In these studies, corporate sustainability is used as social sustainability. In these studies, it was emphasized that it would be possible for an organization to ensure social sustainability by intending to successfully continue its presence in the market for a long time and having credibility and reliability consciousness in all of their activities. The fourth approach involves holistic approaches addressing corporate sustainability. The final and the fourth approach is the holistic approach. Bansal (2005), Gladwin and Kennelly (1995), who approach sustainability in a holistic manner, addressed the concept of sustainability pursuant to the definition of sustainable development of World Commission of Environment and Development of the United Nations, which involves environmental, economic and social dimensions.

It is not possible for us to evaluate the first three approaches (economic, environmental and social), addressed in terms of corporate sustainability, independently from each other. As indicated by Bansal (2005); Gladwin and Kennelly (1995); Benn et al (2007) in their studies; Besler (2009) also alleged that each of these approaches had different aspects and effects in itself, and emphasized that these different aspects had to be addressed in interaction with each other rather than separately and independently from each other. In this context, corporate sustainability can be defined as adaptation of economic, social and environmental factors by companies to their activities and strategies for the purpose of creating long term value.

Finally, a limited number of studies based on SMEs should also be added to abovementioned studies addressing corporate sustainability. The first one of these is the study of Yu (2004) addressing determination of sustainability perception, driving 
forces and sustainability obstacles of 58 SMEs operating in China. Another one is the study of Zegarowski (2006) on SMEs providing recruitment and consultancy services. Yet another one is the study conducted by Bos-Brouwers (2010) for analysis of sustainable innovation procedure of SMEs in the Netherlands. The final study is the study of Ciasullo and Troisi (2013) on the observation of integration of corporate strategies with sustainability on a SME operating in Italy and the reflection of such integration on intangible assets.

Although there are many studies in the literature of our country that address concepts contributing to the development of corporate sustainability approach, there are a limited number of studies that identify corporate sustainability as the subject of their researches. These studies concentrate on the period after 2000s (Nemli, 2004; Tokgöz ve Önce 2009; Sarıkaya, Erdoğan ve Kara, 2010; IMKB, SKD ve PwC Türkiye, 2011; Kuşat 2012; Tuna ve Besler, 2013).Only one of the limited number of studies in Turkish literature is focused on the whole country and large scale companies. Nevertheless, there is not any study that exhibits the situation of SMEs.

\section{RESEARCH}

\subsection{Purpose}

Today, corporate sustainability issue has become one of the most important titles that needs to be taken into consideration within strategy determination procedure of companies. Following four purposes have been emphasized in our study focusing on sustainability situations of Turkish SMEs:

Establishing the meaning and importance of sustainability for SMEs.

Finding out the driving forces and obstacles that lead SMEs to sustainability practices.

Establishing the strategic perspective of SMEs regarding sustainability.

Identifying different management tools used by SMEs in sustainability practices.

Furthermore, it was also intended to determine whether a significant difference exists between clusters in terms of variables identified as the meaning attributed by SMEs in our country to sustainability, their strategic approaches to sustainability, their policies regarding sustainability issues, and their sensitivity to environmental and social issues.

\subsection{Sample and Methodology}

Target population of the study comprises of all SMEs operating in Istanbul. Due to restrictions such as time, cost and distance in this study, which has the characteristics of a qualitative research, sampling method was adopted; 350 SMEs operating in food industry in two organized industrial zones (Ikıtelli and Bayrampasa Organized Industrial Zones) in Istanbul were taken as samples and the study was conducted by way of convenience sampling (Yıldırım vd., 2000: 42) based on volunteering. It was attempted to identify sustainability perspectives of companies and driving forces that lead companies to sustainability practices with questions intended for evaluation of conceptual infrastructure of sustainability. Whether companies strategically approached the issue of sustainability and policies of companies on sustainability were researched with questions where it was attempted to identify strategic sustainability perspectives of SMEs. It was attempted to identify management systems (such as ISO-standardized management systems, EMAS or EFQM), specific management tools (such as environmental accounting and reporting, benchmarking or eco-marketing), employee related activities (such as social securities and fringe benefits or corporate child care) and activities at the societal level (such as sponsoring, corporate giving and community programmes) of SMEs with questions intended for determination of their environmental and social sensitivities. In the survey including a total of 26 questions, while there were multiple-choice and five point rating scale questions in parts of the survey pertaining to conceptual infrastructure, strategic approach, environmental and social sensitivity; questions with different rating scales were addressed in the part where policies regarding sustainability issues were inquired. During the study, data obtained by the survey were analysed by SPSS for Windows software package. On the other hand, Cronbach's Alpha coefficients were calculated for reliability analysis in respect of scales used in the study and it was determined that all of such values were over $0,70(0,60 \leq a<0,80)$ (Table 1). This exhibits that scales subjected to Likert Type rating were highly reliable.

Table 1. Reliability Test Results 


\begin{tabular}{|l|l|l|l|}
\hline & $\mathrm{n}$ & $\overline{\mathrm{X}} \pm \mathrm{S} . \mathrm{D}$ & Cronbach's Alpha \\
\hline The meaning attributed to sustainability & 350 & $4.47 \pm 0.36$ & 0.756 \\
\hline Strategic Approach & 350 & $4.36 \pm 0.49$ & 0.865 \\
\hline Sustainability Politic & 350 & $2.35 \pm 0.38$ & \\
\hline Environmental Awareness & 350 & $4.33 \pm 0.37$ & 0.832 \\
\hline Social Awareness & 350 & $4.06 \pm 0.35$ & 0.791 \\
\hline
\end{tabular}

After the pilot study conducted with 50 SMEs, the survey was reviewed and the pilot study was excluded from the sampling. Surveys, reliability of which was tested, were conducted on 350 SMEs operating in food industry in Istanbul. It was ensured that the surveys, conducted by personal interview with the assistance of a professional research company, were completed by senior managers with executive duties in charge of implementation of fundamental strategy and management policies within the enterprise. Survey returns were finalized with the research company, i.e. it was ensured that the desired number of surveys were conducted, and the risk of encountering incomplete and unfinished questionnaires was eliminated. As frequency distributions according to the results of the survey, in terms of the number of employees, of the companies in the sampling (Table 2) were classified pursuant to the regulation1 on SME classification, it was determined that 1 to 9 employees served in 10,6\%, 10 to 49 employees served in $35,4 \%$, and 50 to 249 employees served in $53,7 \%$.

Table 2. Distribution of Company Size of the Sample

\begin{tabular}{|l|l|l|}
\hline & No. of companies & Percentage \\
\hline $1-9$ employees & 37 & 10.6 \\
\hline $10-49$ employees & 124 & 35.4 \\
\hline $50-249$ employees & 188 & 53.7 \\
\hline N/A & 1 & 0.3 \\
\hline Total & 350 & 100.0 \\
\hline
\end{tabular}

\subsection{Analysis and Results}

Research findings shall be analysed in two parts. The first part of the analysis involves descriptive statistics intended for determination of sustainability situations of SMEs. The second part of the analysis shall attempt to classify the distinction in corporate sustainability perspectives of SMEs in the sampling using K-Means technique, which is a non-hierarchical cluster method. This analysis attempted to present a typology of approaches of the companies to sustainability, and it was seen that characteristics of formed groups were different. Following variables were used in non-hierarchical cluster analysis:

The meaning attributed to sustainability

Strategic perspective of sustainability

Policies on sustainability issues

Sensitivity to environmental and social issues

1 The definition of SME, introduced by the "Regulation on Definition, Qualifications and Classification of Small and Medium Sized Enterprises" issued in the Public Gazette no. 25997 of November 18, 2005 and enacted on May 18, 2006. According to the definition; enterprises with 1 to 9 employees were described as micro sized enterprises, enterprises with 10 to 49 employees were described as small sized enterprises and enterprises with 50 to 249 employees were described as medium sized enterprises.

http://www.kosgeb.gov.tr/UserFiles/File/kobi_tanimi.pdf 


\subsubsection{Results of the Descriptive Analysis}

According to the results of the descriptive analysis, $97 \%$ of SMEs stated that the issue of sustainability was relevant to their business transaction styles and they supported their statements by expressing positive opinions on environmental and social issues that are important for sustainability.

Another result of the analysis reveals that $99 \%$ of SMEs consider reputation, $98 \%$ consider reduction of costs and $96 \%$ consider convenient financing and incentives as well as legal arrangement as the factors leading their enterprise to sustainability practices. Percentages show that SMEs consider economic factors as the most effective power for sustainability practices after reputation. Additionally, non-governmental organizations, media, public pressure and advertising/public relations statements were determined as the driving forces that are considered by companies to be less effective (Table 3).

SMEs considered insufficient capital, insufficient expertise and limited time as obstacles for practices to be conducted in terms of environmental and social issues. Reasons such as their financial incapability, organization problems, qualified personnel concerns and the obligation of managers to handle all activities of the enterprise support the obstacles experienced by SMEs in their environmental and social practices.

\section{Table 3. Reasons for Corporate Sustainability Activities}

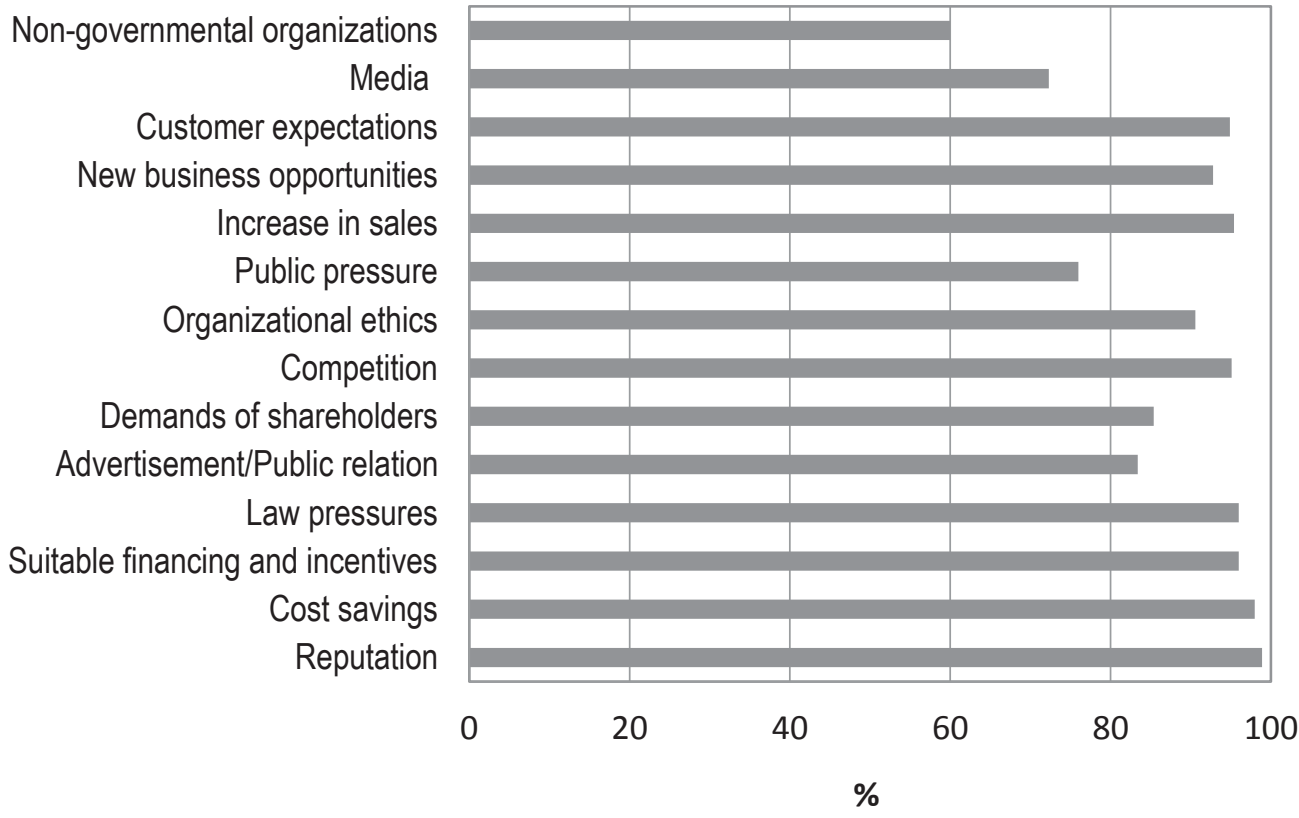

As strategic approaches of SMEs to sustainability and data on company policies in respect of sustainability are addressed; approximately $97 \%$ of SMEs stated that they had sustainability strategies. $95 \%$ consider sustainability as an advantage over competitors, while 95,5\% consider it to be an advantage over companies that they supply to. As regards corporate policies determined by SMEs participating in the survey, it is seen that they have practices and written policies on product safety, accountability, occupational health and safety, customer satisfaction and transparency (Table 4). Furthermore, more than half of the companies have a written policy on water utilization/management and waste management practices. However, it is seen that a considerable part of the SMEs do not have any management policy in respect of climate change and emissions, biodiversity and eco-efficiency. Besides, a considerable part of the companies do not have practices and written policies on social issues such as corruption, sensitivity to human rights, relations with local community and civil society, innovation and discrimination. 
Table 4. Corporate Policy on Sustainability Issues

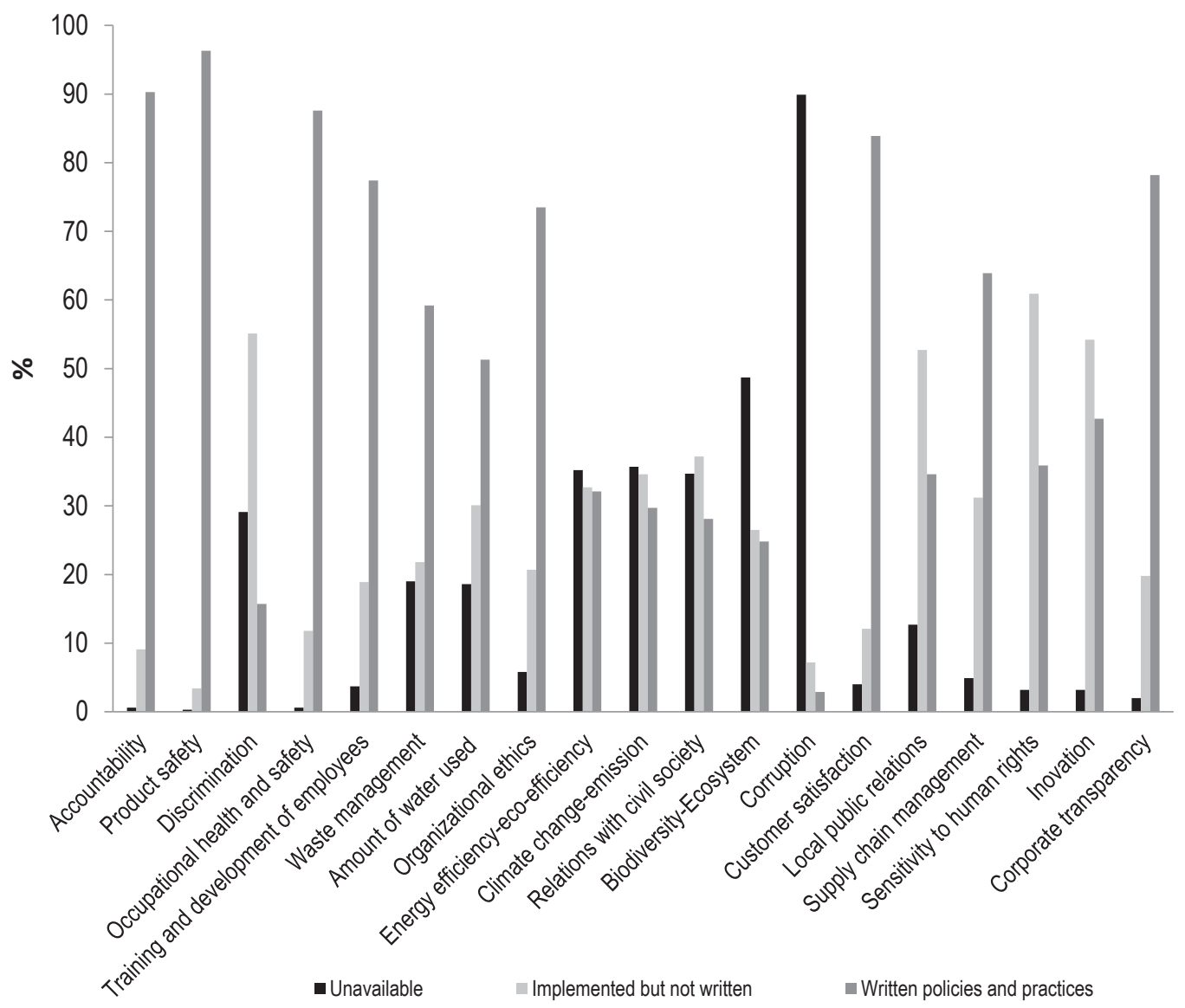

According to evaluations on environmental and social sustainability practices, it is seen that social standards are fall considerably behind certified environmental management systems. For example, while $49,4 \%$ on companies have ISO 14001 and $24 \%$ have EMAS as environmental management tools; $27,4 \%$ have OHSAS $18001,17,4 \%$ have SA8000 and $10,3 \%$ have AA1000 as social management tools. In addition, opinions of the companies were received on issues such as investment to green technology, fighting pollution caused by production, reduction of wastes, improvement of working conditions, discrimination, purchasing from local suppliers that are within the scope of environmental and social issues. (Table 5). 
Table 5. Percentage of Companies Using Different Environmental and Social Management Tools

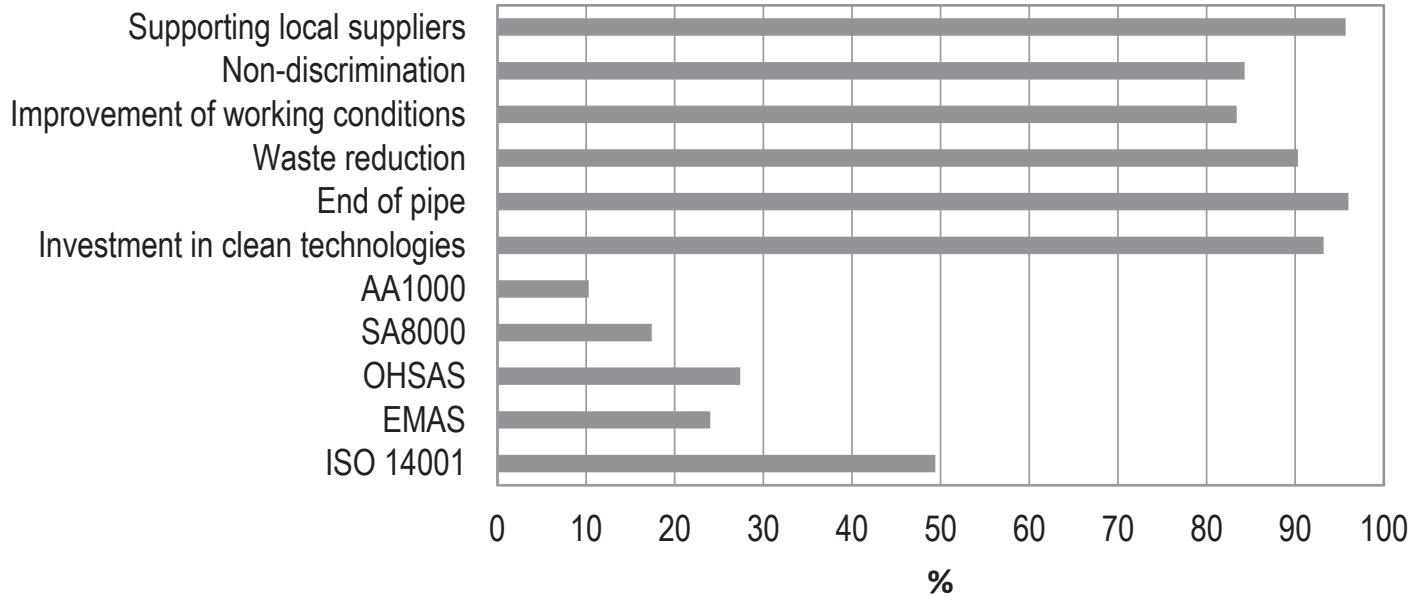

\subsubsection{Results of the Cluster Analysis}

Results of the non-hierarchical cluster analysis exhibit different approaches of the companies in the sampling to sustainability issues in more detail. The result of the cluster analysis allowed us to identify three significantly different groups of companies based on their approach to sustainability issues. As a result of the analysis, it was determined that $48 \%$ of SMEs ( $F=170)$ were in 1 st cluster, $47,8 \%$ were in $(F=167)$ 2nd Cluster and $3,4 \%$ were in ( $F=12) 3$ rd Cluster. A single factor variance analysis was conducted in order to identify whether a significant difference exists between clusters in terms of variables determined as the meaning attributed to sustainability, strategic approach, sustainability policies, environmental sensitivity and social sensitivity. (Table 6). Significant differences were identified for each variable among clusters $(p<0.001)$. Distribution of three types of companies in the sampling was given in Graphic 1.

Table 6. Non-hierarchical Cluster Analysis

\begin{tabular}{|l|l|l|l|l|l|l|l|}
\hline $\begin{array}{l}\text { Cluster } \\
\mathrm{s}\end{array}$ & $\mathrm{n}$ & $\%$ & $\begin{array}{l}\text { The meaning } \\
\text { attributed to } \\
\text { sustainability }\end{array}$ & $\begin{array}{l}\text { Strategic } \\
\text { Approach }\end{array}$ & $\begin{array}{l}\text { Sustainability } \\
\text { Politic }\end{array}$ & $\begin{array}{l}\text { Environment } \\
\text { al } \\
\text { Awareness }\end{array}$ & $\begin{array}{l}\text { Social } \\
\text { Awareness }\end{array}$ \\
\hline & & & $\overline{\mathrm{X}} \pm$ S.D & $\overline{\mathrm{X}} \pm$ S.D & $\overline{\mathrm{X}} \pm$ S.D & $\overline{\mathrm{X}} \pm$ S.D & $\overline{\mathrm{X}} \pm$ S.D \\
\hline 1 & 170 & $48 \%$ & $4.31 \mathrm{~b} \pm 0.37$ & $4.34 \mathrm{~b} \pm 0.27$ & $2.13 \mathrm{~b} \pm 0.30$ & $4.05 \mathrm{~b} \pm 0.26$ & $3.86 \mathrm{~b} \pm 0.23$ \\
\hline 2 & 167 & $\begin{array}{l}47.8 \\
\%\end{array}$ & $4.63 \mathrm{a} \pm 0.25$ & $4.52 \mathrm{a} \pm 0.23$ & $2.60 \mathrm{a} \pm 0.27$ & $4.62 \mathrm{a} \pm 0.19$ & $4.29 \mathrm{a} \pm 0.30$ \\
\hline 3 & 12 & $3.4 \%$ & $4.24 \mathrm{~b} \pm 0.29$ & $2.34 \mathrm{c} \pm 0.57$ & $1.82 \mathrm{c} \pm 0.18$ & $3.90 \mathrm{~b} \pm 0.27$ & $3.69 \mathrm{c} \pm 0.30$ \\
\hline $\mathrm{F}$ & & & 45.240 & 310.80 & 140.915 & 278.977 & 112.698 \\
\hline $\mathrm{P}$ & & & $0.000^{*}$ & $0.000^{*}$ & $0.000^{*}$ & $0.000^{*}$ & $0.000^{*}$ \\
\hline
\end{tabular}

$(p<0,001) ; a, b, c$ : the difference between groups containing different letters is important.

As medians are examined, it is seen that 167 SMEs in the 2nd Cluster have higher medians than companies in other clusters in terms of the meaning attributed to sustainability, strategic approach to sustainability, sensitivity to policy, environmental and social issues. Therefore, it can be said that they are more sensitive to issues regarding sustainability. Accordingly, it would not be wrong to call the companies in the 2nd cluster as 'sustainability leaders'. It is possible to remark that the companies in this group are interested in sustainability and they consider underlying social and environmental 
issues to be important. The reason for the interest of these companies in environmental and social issues can be listed as reputation, reduction of costs, convenient financing and incentives as well as legal arrangement. Sustainability leaders differ from other two clusters particularly in terms of their sensitivity to environmental and social issues. Besides, it is an interesting finding that $61 \%$ of international companies and $86 \%$ of foreign-owned companies in the sampling are in this group. This can be attributed to the sensitivity of international market to the issue of sustainability. Particularly the increase of environment friendly consumption behaviour of consumers in foreign countries, as well as adoption of legal arrangements intended for the protection of environment by governments and international organizations increased the sensitivity of SMEs to sustainability.

It is seen that 170 companies in the 1st Cluster have medians close to sustainability leaders in terms of overlapping sustainability with business transaction style, strategic approach to sustainability and development and adoption of policies regarding sustainability issues. However, they fall considerably behind in terms of sensitivity to social and environmental issues. This can be considered as the indicator that the companies in this cluster mostly concentrate their policies on legally imposed issues and conduct their activities with external pressure. Such an approach causes us to characterize these companies as 'reactive'. The reason for is that the companies in this cluster improve as a reaction to external pressures regarding environmental and social issues. However, corporate sustainability require integration of all issues within the scope of sustainability with management strategy, and a proactive perspective.

It is seen that 12 companies in the 3rd Cluster have lower medians than the others particularly in terms of strategic approach, policy and environmental sensitivity. At the same time, lower medians of the 3rd Cluster than the other clusters in all variables indicate the insensitivity of the companies in this cluster to the issue of sustainability. Therefore, it is possible to characterize the companies in this cluster as 'unconcern'. These companies attribute their insensitivity to the lack of sufficient incentive for sustainability.

\section{Graphic 1. Distribution of the Three Company Types with Respect to Sustainability}

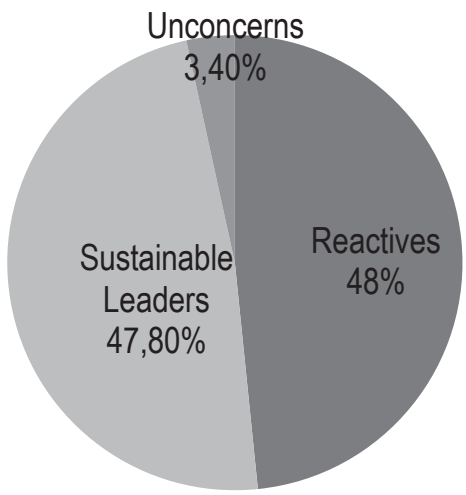

\section{Conclusions}

It is seen that the SMEs in our country have failures in understanding and implementing sustainability. $97 \%$ of the companies stated that they were interested in sustainability and underlying social and environmental issues were considered by the companies to be important. Nevertheless, the fact that sustainability is evaluated mostly in terms of its economic aspect raises concern. Bonda and Sosnowchik (2006) linked economic sustainability to developments that yield monetary gain, job creation, lower energy use, decrease in water expenses, utilization of tax incentives, as well as efficiency caused by light, heat and air conditioning control. It was determined in the research by ACCA (2012) on SMEs at a global level that SMEs concentrated on practices yielding monetary gain such as decreasing energy use, water bills, pollution, transportation costs and compliance with laws. In this context, when results pertaining to the SMEs in our country were evaluated, it was determined that almost $99 \%$ of the companies considered corporate reputation as the most important motivator for sustainability, which was followed by the reduction of costs, financing and incentives, increase in sales and competition. These factors, which closely follow reputation, overlap with practices yielding monetary gain pointed out by 
Bonda and Sosnowchik (2006) in their definitions and global research results of ACCA. Therefore, it would not be wrong to state that the source of reputation for SMEs in our country is based on economic factors.

Approximately $97 \%$ of SMEs stated that they had sustainability strategies and expressed their tendency in this direction. Nevertheless, it was seen that management policies were heavily concentrated on legally controlled issues and many environmental and social issues were ignored. Furthermore, it was determined that few SMEs met the standards corresponding to these issues in formal management systems. It is considered that SMEs in need of financial resources and expertise would have difficulty in establishment and maintenance of sustainability strategy that requires dedication. Besides, concentration of management policies mostly on legally controlled issues is accepted as an indicator that activities are conducted under external pressure and does not overlap with the proactive perspective.

Many studies (Hahn ve Scheermesser, 2006; Atkinson, 2000; Huizing ve Dekker, 1992; Kaptein ve Wempe, 2001) have been conducted for the purpose of identification of what the different management tools used in sustainability practices are. It is seen that many tools were suggested in these studies for measurement and management of sustainability. Tools used in sustainability practices are classified as studies on management systems (ISO standards, such as EMAS and EFQM.), environmental management tools (such as sustainable product design, recycling activities and green technology), activities toward employees (such as improvement of working conditions, flexible working and working at home) and increasing social welfare (such as sponsorship, provision of educational opportunities, supporting local suppliers). It is seen that social standards in SMEs fall considerably behind in comparison with certified environmental management systems.

When the results non-hierarchical cluster analysis were evaluated, three different enterprise typologies were presented in terms of their approaches to sustainability issues. Significant differences were identified in corporate sustainability perspectives of the companies in these clusters, which we called sustainability leaders, reactives and uncorcerns. High percentages of sustainability leaders in all variables identified for cluster analysis can be accepted as an indicator that these companies integrated sustainability into their management strategies. From this perspective; low percentages of reactives and uncorcerns particularly in sustainability practices indicate that the companies in this cluster have problems in adopting sustainability. Hahn and Scheermesser (2006) also conducted a similar study on clustering on 195 German companies. Authors also identified three different clusters and characterized these clusters as sustainability leaders, environmentalists and traditionalists. The literature does not contain any other study that attempts to determine the perspectives of companies in respect of sustainability issues by cluster analysis.

As we generally evaluate the findings, it would be correct to indicate that sustainability practices, which are conducted inadequately by Turkish SMEs, are caused by the pressure of large scale companies of which the SMEs are suppliers or subcontractors, or the obligation to comply with legal arrangements.

\section{References}

Atkinson, G. (2000). Measuring Corporate Sustainability, Journal of Environmental Planning and Management, 43(2): 235252.

Bansal, P. (2005). Evolving Sustainabily: A Longitudinal Study Of Corporate Sustainable Development, Strategic Management Journal, 26 (3), 197-218.

Benn, S., Dunphy, D. \& Griffiths, A. (2006). Enabling Change for Corporate Sustainability: An Integrated Perspective, Australasian Journal of Environmental Management, Volume 13: 156-165.

Besler, S. (Ed.) (2009). Yönetim Yaklaşımlarıyla Kurumsal Sürdürülebilirlik, Beta, İstanbul.

Bos-Brouwers, H.E.J. (2010). Corporate Sustainability and Innovation in SMEs: Evidence of Themes and Activities in Practice, Business Strategy and the Environment, Vol. 19: 417-435.

Callado, A.L.C.\& Fensterseifer, J.E. (2011) Corporate Sustainability Measure From An Integrated Perspective: The Corporate Sustainability Grid (CSG), IJBIT, Vol. 3, Issue. 3: 44-53.

Carroll, A.B. (1999). Corporate Social Responsibility, Business and Society, Vol.38, No.3:268-295.

Ciasullo, M.V.\& Troisi, O.(2013). Sustainable Value Creation in SMEs: A Case Study, The TQM Journal, Vol. 25 No. 1: 4461.

Friedman, M. (1970). A Friedman Doctrine - The Social Responsibility of Business to Increase Its Profits, New York Times, 13 September: 32-33.

Gao, S. \& Zhang, J. (2006). Stakeholder Engagement, Social Auditing and Corporate Sustainability, Business Process Management Journal, Vol. 12, No. 6: 722-740. 
Gladwin, T. N. \& Kennelly, J. J. (1995). Shifting Paradigms for Sustainable Development: Implications for Management Theory and Research, Academy of Management Review, 20(4), 874-907.

Hahn, T. \& Scheermesser, M. (2006). Approaches to Corporate Sustainability among German Companies, Corporate Social Responsibility and Environmental Management, Vol. 13: 150-165.

IMKB (2011). Türk İ̧ Dünyası'nda Sürdürülebilirlik Uygulamaları Değerlendirme Raporu, Eylül. http://www.tbcsd.org/ (Erişim tarihi: 25.04.2013).

Kuşat, N.(2012). Sürdürülebilir İşletmeler İçin Kurumsal Sürdürülebilirlik ve İçsel Unsurları, Afyon Kocatepe Üniversitesi IïBF Dergisi, C.XIV, S. II: 227-242.

Levitt, T. (1958). The Dangers of Social Responsibility, Harvard Business Review, 36(5):41-50.

Linnenluecke, M. K., Russell, S. V. \& Griffiths, A. (2009). Subcultures and Sustainability Practices: the Impact on Understanding Corporate Sustainability, Business Strategy and the Environment, Vol. 18: 439-452.

Marrewijk, M.V. (2003). Concepts and Definitions of CSR and Corporate Sustainability: Between Agency and Communion, Journal of Business Ethics, Vol. 44: 95-105.

Montiel, I. (2008). Corporate Social Responsibility and Corporate Sustainability Separate Pasts, Common Futures Organization \& Environment, Vol. 21, №. 3: 245-269.

Nemli, E. (2004). The Status Of Corporate Sustainability In Turkish Companies, Second Global Compact Academic Conference, Pensylvania, U.S.A., September 16-18:1-19.

Robinson vd. (2006) STEPS: A Knowledge Management Maturity Roadmap for Corporate Sustainability, Business Process Management Journal, Vol. 12 No. 6: 793-808.

Salzmann, O., Somers, A.I. \& Steger, U. (2005). The Business Case For Corporate Sustainability: Literature Review And Research Options, European Management Journal, Vol. 23, No. 1.

Sarıkaya, M., Erdoğan, M. ve Kara, F.Z. (2010) İnternet Ekonomisi ve Kurumsal Sürdürülebilirlik, Eskişehir Osmangazi Üniversitesi İ̈BF Dergisi, Ekim, 5(2), 31-50.

Schneider, A. \& Meins, E. (2011). Two Dimensions of Corporate Sustainability Assessment: Towards a Comprehensive Framework, Business Strategy and the Environment.

Sharma, S. \& Ruud, A. (2003). Editorial on the Path to Sustainabilty: Integrating Social Dimensions Into the Research and Practice of Environmental Management, Business Strategy and the Environment, 12: 205-214.

Shrivastava, P. (1995). The Role Of Corporatıons In Achıevıng Ecologıcal Sustaınabılıty, Academy of Management Review, Vol. 20, No. 4: 936-960.

Signitzer, B., Prexl, A.(2008) Corporate Sustainability Communications: Aspects of Theory and Professionalization, Journal of Public Relations Research, 20:1-19.

Starik, M. and Rands, G.P. (1995). Weaving an Integrated Web:Multilevel and Multisystem Perspectives of Ecologically Sustainable Organizations, The Academy of Management Rewiew, 20(4):908-935.

The World Business Council for Sustainable Development (WBCSD) (2004). Promoting Small and Medium Enterprises for Sustainable Development, Development Focus Area, Issue Brief.

Tokgöz, N. ve Önce, S. (2009) Şirket Sürdürülebilirliği: Geleneksel Yönetim Anlayışına Alternatif, Afyon Kocatepe Üniversitesi I.I.I.B.F. Dergisi, C.X I,S. I: 249-275.

Tuna, Ö.ve Besler, S. (2013) Kurumsal Sürdürülebilirlik Stratejileri: Örnek Olay Çalışması,12.Işletmecilik Kongresi, 2-4 Mayıs.

Wilson, M. (2003). Corporate Sustainability: What Is It And Where Does It Come From?, Ivey Business Journal Online, Vol.1, Mar/Apr.

Yıldııım vd. (2001). Sosyal bilimlerde Nitel Araştırma Yöntemleri, 2.Baskı, Seçkin Yayıncılık, Ankara.

Young, W. \& Tilley, F. (2006). Can Businesses Move Beyond Efficiency? The Shift Toward Effectiveness And Equity İn The Corporate Sustainability Debate, Business Strategy and the Environment, Volume 15, Issue 6: 402-415.

Yu, J. (2004). Building a Sustainable Business in Chinese Small and Medium-sized Enterprises (SMEs), Imperıal College London Faculty Of Life Sciences, Department of Environmental Science \& Technology.

Zegarowski, G. (2006). Corporate Sustainability After Sarbanes - Oxley Linking Social - Political Initiatives and Small and Medium-Sized Enterprise Resources, International Journal of Disclosure and Governance, Vol. 4: 52-58. 